\title{
AKUNTANSI UNTUK CRYPTOCURRENCY
}

\author{
Ayke Nuraliati' ${ }^{1}$, Peny Cahaya Azwari' ${ }^{2}$ \\ ${ }^{1}$ Universitas Langlang Buana \\ aykenuraliati@gmail.com \\ ${ }^{2}$ Universitas Islam Negeri Raden Fatah Palembang \\ penycahayaazwari_uin@radenfatah.ac.id
}

\begin{abstract}
Cryptocurrency in Indonesia has begun to develop and is starting to be widely used by business people in Indonesia. This is a phenomenon in view of the need for accounting treatment for cryptocurency transactions. This research attempts to explore and test cryptocurrency and blockchain technology with the approach and review of PSAK in Indonesia and focus on the accounting treatment for cryptocurrency in Indonesia. The purpose of this study is to conduct a study of accounting for crytocurrency based on the applicable PSAK in Indonesia. This study uses a review literature model to find out accounting for cryptocurrency. The results of the study indicate that there is no accounting treatment for cryptocurrency transactions whether treated as cash, assets, or inventory.
\end{abstract}

Key words: Cryptocurency, AccountingTreatment, Bitcoin, Digital Currency.

\section{PENDAHULUAN}

Cryptocurrency atau mata uang digital menggunakan transaksi melalui jaringan (online). Cryptocurrency, kosakata turunan dari kata cryptography atau kriptografi (bahasa persandian), merujuk kepada sebuah kesepakatan dari para pengguna dan proses penyimpanan yang diamankan oleh sandi-sandi yang kuat, sedangkan currency adalah mata uang sebagai alat pertukaran yang berlaku di masyarakat. Cryptocurrency adalah sistem mata uang yang terpusat berupa jaringan yang mampu menghubungkan penggunanya tanpa perantara atau pihak ketiga seperti perbankan atau pemerintah.Crytocurency bermula darimencari jawaban atas permasalahan yang dihadapi sistem pembayaran dewasa iniyang bergantung kepada pihak ketiga sebagai perusahaan produk pembayaran yang dapat di percaya untuk mengelola transaksi digital seperti Visa Paypal dan lainnya (Syamsiah 2017).

Bank Indonesia membagi 2 jenis instrumen sistem pembayaran yaitu tunai dan nontunai, terdiri dari: Instrumen pembayaran tunai berupa uang kertas atau uang coin dan instrument non tunai atau Digital Money/ Electronic Money merupakan alat atau instrumen pembayaran non tunai. Perkembangan e-money di Indonesiamenciptakan suatu trendless cash society, yaitu suatu perilaku masyarakat menggunakan transaksi non tunai dengan memanfaatkan kemudahan-kemudahan yang ditawarkan oleh alat-alat transaksi elektronik tersebut, antara lain kecepatan dan efisiensi dalam melakukan transaksi (waspada, 2012).Penggunaan e-money di rasalebih nyaman dibandingkan uang tunai, untuk transaksi bernilai kecil,karena nasabah tidak perlu mempunyai sejumlah uang pas untuk transaksi, serta kesalahan dalam menghitung dapat dikurangi.Gormez \& Capie (2003) menjelaskan bahwa e-money akan memengaruhi industri jasa keuangan di masa depan dan mampu mengurangi barrier dalam mengakses industri jasa keuangan. 
Penggunaan Cryptocurrencysebagai alat pembayarandi Indonesia masih kecil yaitu 0,02\%dari pangsa seluruh dunia. Di Indonesia sudah ada lebih dari 50 merchant cryptocurrency baik untuk transaksi online maupun transaksi offline, khususnya bitcoin bisa dilihat pada situs http://directory.bitcoin.co.id/. Walaupun didominasi oleh usaha restoran dan penginapan, namun hal ini sudah cukup membuktikan eksistensinya di negeri ini (Syamsiah 2017). Dapat disimpulkan adanya potensi yang besar di masa depan yang disebabkan pertumbuhan yang pesat sebagai antisipasi perkembangan teknologi. Hal ini membuat cryptocurrencyperlu diatur dan mendapat kepastian hukum serta perhatian dari otoritas yang berwenang seperti perbankan dan otoritas perpajakan.

\section{LITERATUR REVIEW}

Kas

Kas diwakili oleh benda fisik, biasanya koin atau catatan (Berentsen dan Schair 2018). PSAK Nomor 2 mengatakan bawa kas terdiri atas saldo kas (cash on hand) dan rekening giro (demand deposits). Kas fisik di mana objek diserahkan ke individu lain, unit nilainya juga ditransfer, tanpa perlu melibatkan pihak ketiga. Digital Cash.

Sistem pembayaran yang ideal adalah sistem ketika nilai uang dapat ditransfer secara elektronik melalui file data kas (Berentsen dan Schair 2018). Konvisser (1997) menyatakan asal mulainya transaksi digital kas adalah berasal dari kartu kredit kemudian pemeriksaan digital di mana pembeli memiliki akun bank on-line yang bisa digunakan untuk cek. File ini tentu dapat disalin beberapa kali dengan biaya yang relatif tidak ada artinya kemudian bila file ini di salin beberapa kali dan duplikatnya digunakan sebagai mata uang maka mereka tidak bisa berfungsi sebagai mata uang. Masalah ini disebut pengeluaran ganda.

\section{Electronic Payment Systems}

Untuk mengatasi masalah pengeluaran ganda, sistem pembayaran elektronik klasik didasarkan pada otoritas pusat yang memverifikasi keabsahan pembayaran dan melacak keadaan kepemilikan saat ini. Dalam sistem seperti itu, otoritas pusat (biasanya bank) mengelola akun pembeli dan penjual. Pembeli memulai pembayaran dengan mengirimkan pesanan. Otoritas pusat kemudian memastikan bahwa pembeli memiliki dana yang diperlukan dan menyesuaikan akun.(Berentsen dan Schair, 2018).

Sistem ini membutuhkan kepercayaan. Agen harus percaya otoritas pusat/ bank tidak menyalahgunakan kekuasaan yang didelegasikan dan mempertahankan buku-buku dengan benar di negara manapun. Selain itu sistem ini rentan dengan peretas dan kegagalan teknis.

\section{Blockchain}

Koin digital / elektronik adalah sebuah nilai nominal yang dapat ditransaksikan, dimana koin digital ini merupakan sebuah rangkaian digital signature yang saling terhubung (Mulyanto: 2015). Koin digital/ elektronik adalah unit moneter virtual oleh karena itu tidak memiliki representasi fisik(Berentsen dan Schair, 2018). Konsep dasar koin digital/ elektronik yaitu membuat sistem decentralized authority transaction tanpa adanya pihak ketiga yang dapat melakukan verifikasi dengan menggunakan konsep digital signature pada setiap transaksi (Nakamoto, 2008). Dapat dikatakan bahwa bitcoin,Litecoin, dan Dogecoin adalah coin virtual dan merupakan jenis dari Cryptocurrency. 


\section{Sistem Pembayaran di Indonesia}

Sistem pembayaran di indonesia dapat dikategorikan menjadi sistem pembayaranmanual danuang elektronik. Kategori alat pembayaran yang berlaku di Indonesia:

Tabel 1

Kategori Alat Pembayaran

\begin{tabular}{cll}
\hline No & Kategori Alat Pembayaran & Jenis \\
\hline 1 & Uang Kartal ( logam dan kertas ) & Fisik \\
\hline 2 & Uang Giral / Giro / Cek & Fisik \\
\hline 3 & APMK ( Alat Pembayaran Menggunakan Kartu ) & Fisik \\
\hline 4 & Uang Elektronik & Digital \\
\hline
\end{tabular}

Sumber: Mulyanto (2015)

Sistem pembayaran elektronik dikenal dengan nama digital currency, digital money, digital cash, virtual currency, virtual money, virtual cash, e-money, e-cash, cryptocurrency. E-money menurut Peraturan Bank Indonesia No.11/12/PBI/2009 tentang Uang Elektronik (emoney) adalah alat pembayaran yang memenuhi syarat syaratantara lain:

1. Diterbitkan atas dasar nilai uang yang disetor terlebih dahulu oleh pemegang kepada penerbit.

2. Nilai uang disimpan secara elektronik dalam suatu media seperti server atau chip.

3. Digunakan sebagai alat pembayaran kepada pedagang yang bukan merupakan penerbit uang elektronik tersebut.

4. Nilai uang elektronik yang disetor oleh pemegang dan dikelola oleh penerbit bukan merupakan simpanan sebagaimana dimaksud dalam undang-undang yang mengatur mengenai perbankan.

Di Indonesia uang elektronik jumlahnya banyak dan beragam jenisnya, tidak hanya perbankan yang mengeluarkan uang elektronik di indonesia hingga pemain selularpun dan aplikasi mengeluarkan uang elektronik. Contohnya Flazz dari BCA dan jenis data berbentuk chip. Dari Bank Mandiri memiliki E-Money denganjenis data berbentuk chip. Telkomsel dengan T-cash dengan jenis data berbentuk Server, dan lain-lain.

\section{Bitcoin}

Bitcoin adalah uang elektronik atau asset digitalyang dibuat pada tahun 2009 oleh Satoshi Nakamoto. Bitcoinmerupakan salah satu implementasi pertamadari cryptocurrency, pertama kali dideskripsikanoleh Wei Dai tahun 1998 dalam milis cypherpunks.Mekanisme yang terjadi pada transaksi menggunakan Bitcoin ada empat macam, yaitu: Mining, Exchange, Commerce, dan Investment. (Syamsiah 2017):

1. Mining/Penambangan

Sama seperti mata uang konvensional yang terbuat dari kertas atau koin, Bitcoin juga tidak mempunyai nilai intrinsik. Mereka nyaris tidak punya nilai sama sekali jika tidak ada sistem mekanisme yang menjamin nilai dari mata uang tersebut. Bila sistem mekanisme yang menjamin nilai mata uang konvensional adalah Bank Sentral dengan segala pekerjaannya, maka sistem mekanisme yang menjamin nilai Bitcoin adalah suatu perhitungan matematis rumit yang dilakukan oleh semua penggunanya dengan menggunakan software dan hardware khusus. Sebagai imbalan atas partisipasi dalam sistem mekanisme tersebut, setiap pengguna akan mendapat imbalan berupa Bitcoin. 
Proses partisipasi dalam sistem dengan imbalan Bitcoin inilah yang dikenal sebagai Mining atau penambangan.

2. Exchange / pertukaran

Bitcoin dapat diperoleh tanpa melakukan mining dengan mendatangi Exchanger. Contohnya di Indonesia exchanger Bitcoin adalah PT Bitcoin Indonesia. Selain untuk membeli dan menjual serta mentransfer dan melakukan deposit Bitcoin, biasanya Exchanger memungut biaya atas jasa yang diberikan. Exchanger juga mendapat keuntungan dari spread kurs jual dengan kurs beli. Vending machine yang melayani penukaran Bitcoin dengan mata uang konvensional, seperti layaknya ATM, juga masuk dalam kategori exchange ini.

3. Commerce

Bitcoin dan mata uang virtual lainnya, sejatinya diciptakan untuk tujuan perdagangan (commerce). Penyedia barang atau jasa dapat melakukan transaksi dengan pembeli yang membayar dengan Bitcoin. Penyedia barang dan jasa yang bersedia dibayar dengan Bitcoin biasa disebut sebagai Merchant. Jumlah Merchant yang terdaftar di marketplace Bitcoin Indonesia sudah lebih dari 3.000 pada tanggal 16 Maret 2014. Padahal market place ini baru diluncurkan pada tanggal 15 Februari 2014.

4. Investment.

Bitcoin, sebagaimana mata uang konvensional, juga dapat digunakan orang sebagai instrumen investasi. Masyarakatmelihat bitcoin sebagai alat investasi atau spekulasi dibandingkan sebagai fungsinya yang lain. Hal inidapatdisebabkankarenatidak ada alat spekulasi yang lebih menggiurkan dari bitcoin sekarang ini. Dalam waktu setahun nilai bitcoin naik hampir 90 kali lipat.Perbedaan dari uang elektronik saaat ini dengan uang elektronik yang menggunakan cryptocurrency menurut Mulyanto (2015):

Tabel 2

Perbandingan Uang Elektronik Dengan Bitcoin/Cryptocurrency

\begin{tabular}{lll}
\hline $\begin{array}{c}\text { Faktor } \\
\text { Penilaian }\end{array}$ & \multicolumn{1}{c}{ Uang elektronik saat ini } & \multicolumn{1}{c}{$\begin{array}{c}\text { Uang elektronik menggunakan } \\
\text { cryptocurrency }\end{array}$} \\
\hline Keamanan & $\begin{array}{l}\text { Rentan terjadi manipulasi data, } \\
\text { tergantung teknologi masing- } \\
\text { masing penyedia layanan }\end{array}$ & $\begin{array}{l}\text { Cukup aman, karena menggunakan } \\
\text { kriptografi }\end{array}$ \\
\hline Kecepatan & $\begin{array}{l}\text { Relatif terhadap penyedia layanan } \\
\text { namun cenderung ebih cepat }\end{array}$ & $\begin{array}{l}\text { Cenderung lebih lama dibandingkan } \\
\text { dengan uang elektronik umumnya } \\
\text { seluruh perbankan yang terdaftar } \\
\text { pada Bank Indonesa }\end{array}$ \\
\hline Biaya & Biaya setiap penyedia beragam & $\begin{array}{l}\text { Biaya cenderung lebih murah karena } \\
\text { penyedia tidak perlu membangun } \\
\text { infrastuktur masing-masing }\end{array}$ \\
\hline Kompatibilitas & $\begin{array}{l}\text { Tidak semua penyedia layanan } \\
\text { bisa saling mendukung transaksi } \\
\text { finansial }\end{array}$ & $\begin{array}{l}\text { Semua penyedia layanan perbankan } \\
\text { dapat saling sinkronisasi data } \\
\text { nasabah menggunakan konsep } \\
\text { shared ledger }\end{array}$ \\
\hline Kemudahan & $\begin{array}{l}\text { Cukup mudah dan cepat untuk } \\
\text { Melakukan transaksi, karena alat } \\
\text { pembayaran didekatkan dengan } \\
\text { terminal akses pembayaran }\end{array}$ & $\begin{array}{l}\text { Lebih cepat dari uang elektronik saat } \\
\text { ini, cukup memasukan public address } \\
\text { tujuan pengiriman dana. }\end{array}$ \\
\hline
\end{tabular}


Dannella et al (2015) menyatakan perbandingan bit coin dengan mata uang legal lainya antara lain dapat dilihat dari tabel 3:

Tabel 3

Perbandingan Bitcoin Dengan Mata Uang Lainnya

\begin{tabular}{lllll}
\hline \multicolumn{1}{c}{ Bitcoin } & \multicolumn{3}{c}{ Mata Uang Lainnya } \\
\hline $\begin{array}{l}\text { Menggunakan teknologi peer-to-peerdan } \\
\text { tanpa otoritas pusat atau lembaga untuk } \\
\text { mengawasi operasi }\end{array}$ & $\begin{array}{l}\text { Dikeluarkan oleh bank sentral sebagai } \\
\text { bentuk dari kewenangannya mengelola } \\
\text { kebijakan moneter nasional }\end{array}$ & \\
\hline $\begin{array}{l}\text { Bitcoin dirancang untuk menjadi mata } \\
\text { uang digital }\end{array}$ & Diciptakan dalam bentuk fisik & \\
\hline $\begin{array}{l}\text { Jumlah bitcoin yang diproduksi dibatasi } \\
\text { sampai 21 juta }\end{array}$ & Dapat diterbitkan tanpa batas & \\
\hline $\begin{array}{l}\text { Membutuhkan tingkat pengetahuan yang } \\
\text { tinggi karena menggunakan teknologi } \\
\text { cryptocurrency }\end{array}$ & $\begin{array}{l}\text { Tidak membutuhkan teknologi dan } \\
\text { pemahaman mendalam }\end{array}$ & dan \\
\hline $\begin{array}{l}\text { Penerimaan masih terbatas, hanya dapat } \\
\text { digunakan di toko-toko tertentu }\end{array}$ & Dapat digunakan dan diterima dimana saja \\
\hline
\end{tabular}

Legalitas Bitcoin di indonesia belum diakui oleh Bank Indonesia sebagai alat pembayaran karena tidak sesuai dengan Undang-undang no 7 tahun 2011 tentang Mata Uang dan Undang-undang no. 23 tahun 1999 tentang Bank Indonesia. Dalam undangundang Mata Uang dinyatakan bahwa mata uang adalah uang yang dikeluarkan oleh Bank Indonesia sebagai bank sentral yang disebut rupiah, dan dalam Undang-undang Bank Indonesia dinyatakan mata uang yang sah beredar di Negara Republik Indonesia adalah uang rupiah. Hal ini diperkuat pula dengan Peraturan Bank Indonesia Nomor 17/3/PBI/2015 Tentang Kewajiban Penggunaan Rupiah karena Rupiah wajib digunakan untuk segala transaksi yang ada di wilayah Negara Kesatuan Republik Indonesia, penggunaan alat pembayaran lain selain Rupiah di Indonesia dapat dikenakan sanksi pidana baik kurungan maupun dendam kecuali pada perbuatan-perbuatan yang dikecualikan dalam Undang-Undang Nomor 7 Tahun 2011 Tentang Mata Uang.

Danella et al (2015) berpendapat bahwa bitcon memenuhi syarat sebagai alat pembayaran yang sah antara lainkarena:

1. Tidak mudah rusak.

2. Mempunyai kualitas yang cenderung sama.

3. Tidakdapat dipalsukan

4. Mudah dibawa

5. Mempunyai nilai yang stabil

Dapat disimpulkan bitcoin bisa dipakai sebagai alat pembayaran yang sah, namunbelumtersedia regulasi dari pemerintah dan tidak ada landasanhukumataspenggunaan bitcoin.

\section{METODE PENELITIAN}

Penelitian ini adalah penelitian dengan metode kajian pustaka, dimana menggunakan data-data pustaka sebagai sumber data utama. Sebuah tinjauan literatur adalah deskripsi dari studi yang relevan dengan bidang ataupun topik tertentu. Pembahasannya tentang 
informasi dalam bidang subjek tertentu dengan referensi terbaru yakni beberapa tahun terakhir. Prosesnya antara lain membaca, menganalisis, mengevaluasi dan meringkas materi secara spesifik.

Dalam konteks ini, telah dilakukan tinjauan literatur tentang kondisi cryptocurrency di Indonesia. Dengan demikian, tujuan dari tinjauan literatur ini adalah untuk memberikan pandangan dari penelitian-penelitian yang telah ada sebelumnya.

\section{HASIL PENELITIAN}

Dengan semakin berkembangnya cryptocurencies seperti Bitcoin, Etherum, dan lain lain, maka timbulah pertanyaan bagaimana perlakuan dan pencatatan akuntansi bila perusahaan menerima pembayaran Bitcoin dan juga memiliki Bitcoin untuk berinvestasi.Zigman (2015) menjelaskandalam pengelolaan general ledger ada tiga proses kunci dari praktek akuntansi ketika meggunakan bitcoin dan sejenis yaitu

1. Cara pembayaran

Dalam sistem akuntansi modern ada berbagai metode pembayaran seperti uang tunai, cek, dan kartu kredit. Secara sederhana menentukan media yang digunakan untuk menukar uang. Layanan melakukan pembayaran dengan Paypal, Bitpay, dan sejenisnya akan lebih mudah untuk menerina Bitcoin dan kawan-kawannya untuk mengikuti praktek akuntansi yang digunakan dalam bisnis ini. Umumnya dengan menentukan metode pembayaran dalam software akuntansi,menguhubungkan dengan rekening bank, bahwa ada dana yang menetap, dan kemudian mengikuti prosedur penyedia layanan bitcoin yang mengatur menerima bitcoin dalam sebuah bisnis. Dengan kata lain bit coin diperlakukan sebagai kas atau setara kas yaitu PSAk 1 tentang kas atau PSAK 50 tentang setara kas

2. Mata uang asing

Dengan metode ini,bitcoin diperlakukan sebagai mata uang asing.Hal ini sama seperti ketika menerima euro sebagai mata uang di sebuah organisasi berbasis USD. Maka sistem akuntansi perlu memahami mata uang baru tersebut serta harga valuta terkait. Ketika bitcoin di terima sebagai mata uang asing software akuntansi akan menetapkan harga setiap single transaction relative kepada base currency. Dengan informasi ini akuntan dapat menyusun kembali catatan offline untuk memenuhi persyaratan pelaporan seperti pedoman IRS yang menuntut agar bit coin di perlakukan sebagai property / asetinstrument keuangan, ataupresediaanyaitu PSAK 10 tentang mata uang asing, PSAK 19 tentang aset tidak berwujud, PSAK 50 tentang instrument keuangan, dan PSAK 16 tentang Persediaan

3. Mata uang dasar (Base Curency)

Bitcoin di perlakukan sebagai Base Currencysehingga memperlakukan mata uang lainya sebagai mata uang asing. Organisasi yang menggunakan metode ini harus berlingkup global yaitumemiliki perdagangan, pelanggan, karyawan, pemasok, dan mitra bisnis di mana saja dan di mana-mana. Hal ini akan menhasilkan orientasi yang berbeda, jika organisasi banyak memilih metode ini hal ini akan menjadi cara untuk mengukur apakah bitcoin telah mencapai menerimaan global yang luas.

\section{PEMBAHASAN}

\section{Akuntansi untuk Cryptocurrencies}

Pengakuan akuntansi untuk cryptocurrenciesmenurut PSAK dapatdilihatdaribeberapafaktor, yaitu: 


\section{Cara pembayaran.}

PSAK Cryptocurrencysebagai kas / setara kas

Berdasarkan PSAK 1 pp 66 di katakan entitas dapat mengklasifikasikan aset sebagai aset lancar jika;

a. Entitas memperkirakan akan merealisasi aset, atau memiliki intensi untuk menjual atau menggunakanya dalam siklus operasi normal.

b. Entitas memiliki aset untuk tujuan di perdagangkan;

c. Entitas memperkirakan akan merealisasi aset dalam jangka waktu dua belas bulan setelah periode pelaporan atau

d. Aset merupakan kas atau setara kas (sebagaimana didefinisikan dalam PSAK 2: Laporan arus kas) kecuali aset tersebut di batasi pertukaranya atau penggunaanya untuk menyelesaikan liabilitas sekurang-kurangya duabelas bulan setelah periode pelaporan

PSAK 50 pp 03 mendefinisikan kas (mata uang) yaitu aset keuangan karenamerupakan alat tukar,sedangkan PSAK 2 pp 07 menyatakan setara kas di miliki untuk memenuhi komitmen kas jangka pendek bukan untuk investasi atau tujuan lain. Syaratnya untuk memenuhi kualifikasi kas atau setara kas, suatu investasi harus segera dapat dikonversikan menjadi kas dalam jumlah yang dapat ditentukan dan memiliki resiko perubahan nilai yang tidak signifikan, sehingga investasi dikatakan kas / setara kas jika akan segera jatuh tempo dalam waktu singkat contoh 3 bulan.

Berdasarkan kriteria tersebut Bitcoin dapat diperlakukan sebagai kas atau setara kas karena perusahaan akan merubah bentuk bitcoin menjadi uang dalam waku satu minggu selambatnya satu tahun, sehingga bitcoin bisa ditukarkan / di konversikan dalam bentuk mata uang sebenarnya. Bitcoin dapat di anggap kas atau setara kas jika digunakan sebagai alat tukar, tetapi sebagian besar membeli Bitcoin sebagai investasi seperti membeli emas batangan atau investasi seperti pada pasar modal di mana investasi untuk jangka panjang.

Penggunaan Bitcoin sebagai mata uang relatif kecil. Larangan penggunaan mata uang digital telah tercakup dalam Undang-Undang Nomor 7 Tahun 2011 tentang Mata Uang, dan Peraturan BI Nomor 7/3/PBI/2015 tentang Kewajiban Penggunaan Rupiah. Selain itu ada juga aturan Selain itu ada Peraturan BI Nomor 18/40/PBI/2016 tentang Penyelenggaraan Pemprosesan Transaksi Pembayaran dan Peratruan BI Nomor 19/12/PBI/2017 tentang Penyelenggaraan Teknologi Finansial.

Berdasarkanhaltersebut, timbulpertanyaanapakah Bitcoin akan diperlakukan sebagai mata uang tradisional dan dianggap kas atau setara kas, atau investasi Bitcoin dianggap sebagai aset keuangan dan harus tunduk pada standar PSAK untuk instrumen keuangan? Hal inimasihmenjadikeraguan, dikarenakan PSAK belummengaturjelastentangbitcoinsehinggabitcoinbelumdianggapdapatdiperlakukandala makuntansi.

\section{Mata Uang Asing}

PSAK Cryptocurrency sebagai mata uang asing

PSAK Cryptocurrency terkait mata uang asingdapatdijelaskansebagaiberikut. Suatu transaksi mata uang asing harus dicatat dalam mata uang fungsional. Definisi mata uang fungsional menurut PSAK 10 adalah "mata uang pada lingkungan ekonomi utama dimana perusahaan beroperasi". Pada dasarnya mata uang fungsional adalah mata uang yang digunakan dalam transaksi pengukuran. Berbeda dengan mata uang pelaporan yang digunakan dalam menyajikan laporan keuangan. PSAK 10 mensyaratkan perusahaan 
untuk mengukur transaksinya menggunakan mata uang fungsionalnya dan membolehkan perusahaan menyajikan laporan keuangannya dengan mata uang apa saja. Hal ini disebabkan karena mata uang fungsional diharapkan dapat mencerminkan transaksi peristiwa, dan kondisi mendasari yang relevan. Sekali mata uang fungsional ditentukan, mata uang fungsional tidak berubah.

Faktor dalam menentukan bitcoin sebagai mata uang fungsional adalah bitcoin harus memenuhi kriteria mata uang fungsional sebagai berikut:

a. Paling mempengaruhi harga jual, seringkali menjadi mata uang dimana harga jual untuk barang dan jasa didenominasikan dan diselesaikan;

b. Dari suatu negara yang kekuatan persaingan dan perundang-undangannya sebagian besar menentukan harga jual dari barang dan jasanya; dan

c. Mempengaruhi biaya tenaga kerja, bahan baku, dan biaya lain dari pengadaan barang atau jasa (biaya didenominasikan dan diselesaikan).

PSAK 10 telahmengatur transaksi dengan mata uang asing bahwa transaksi valuta asing adalah transaksi yang didenominasikan atau memerlukan penyelesaian dalam valuta asingtermasuk transaksi yang timbul ketika entitas:

a. Transaksi yang timbul ketika membeli atau menjual barang / jasa yang harganya didenominasikan dalam valuta asing

b. Meminjam atau meminjamkan dana ketika jumlah yang merupakan mata utang atau tagihan didenominasikan dalam valuta asing.

c. Memperoleh atau melepas aset, atau mengadakan, atau menyelesaikan liabilities yang didenominasikan dalam valuta asing

Berdasarkan penjelasan diatas, maka dapat disimpulkan bahwa ketika melihat syarat mata uang fungsional dan mata uang asing, maka bitcoin belum dapat belum diperlakukan sebagai mata uang fungsional.

\section{Bitcoin Sebagai instrument keuangan Aset Instrument keuangan dan Aset}

Perusahaan yang menggunakan bitcoin, memiliki bitcoin ini untuk tujuan investasi sehingga investasi bitcoin dianggap sebagai aset keuangan dan tunduk pada standar PSAK atau IFRS sebagai instrument keuangan tapi Instrumen keuangan (financial instrument) atau sebagai aset tidak berwujud.

PSAK Cryptocurrency Aset Dan Instrument Keuangan

Jika bitcoin dianggap instrumen keuangan (financial instrument), menurut PSAK 50 pp 11 yang dianggap instrumen keuanganadalah kontrak yang mengakibatkan timbulnya aset keuangan bagi satu entitas dan kewajiban keuangan atau instrumen ekuitas bagi entitas lainnya, di mana setiap kontrak menambah nilai aset keuangan entitas dan liabilitas keuangan atau instrumen keuangan lainya. Bitcoin dalam hal ini tidak memenuhi hak kontraktual untuk menerima kas atau aset keuangan, hal ini serupa dengan emas batangan yang juga tidak bisa dianggap sebagai instrumen keuangan walaupun likuid.

Aset menurut PSAK 19 dan IFRS adalah aset adalah sumber daya yang dikendalikan oleh perusahaan sebagai akibat dari peristiwa masa lalu dan manfaat ekonomi masa depan yang diharapkan mengalir pada perusahaan. PSAK 19 menyatakan aset tidak berwujud adalah aset non moneter terindentifikasi tanpa wujud fisik, dalam hal ini aset tidak berwujud kategori tidak lancar yang dimanfaatkan atau digunakan oleh perusahaan seperti misalnya yang dimaksud adalah goodwill, hak paten, hak merek, royalti, piranti lunak dan sebagainya. 
Kriteria pengakuan aset tidak berwujud PSAK 19 pp21-23:

a. Aset tidak berwujud di akui jika dan hanya

1) Kemungkinan besar entitas akan memperoleh manfaat ekonomi masa depan dari aset tersebut

2) Biaya perolehan aset tersebut dapat di ukur secara handal

b. Dalam menilai kemungkinan menggunakan asumsi masuk akal dan dapat di pertanggungjawabkan yang merepresentasikan estimasi terbaik manajemen

c. Mempertimbangkan bukti yang tersedia pada saat pengakuan aset tidak berwujud dengan memberikan penekanan yang lebih besar pada bukti eksternal.

Suatu aset di katakan sebagai aset tidak berwujud menurut PSAK 19 pp18 suatu aset terindetifikasi sebagai aset tidak berwujudjika :

a. Definisi aset tidak berwujud ( pp 8 -17)

b. Kriteria pengakuan (pp 21-23)

Bitcoin memenuhi definisi aset tidak berwujud karena tidak memiliki bentuk fisik dan bersifat non keuangan dan memenuhi definisi aset. Namun bitcoin tidak memenuhi PSAK19 kategori tidak lancar yang dimanfaatkan atau digunakan oleh perusahaan seperti misalnya hak paten, merk, royalti, piranti lunak, dan sebagainya. Bila bitcoin dimiliki sebagai alat pembayaran,bitcoin sebagai alat pembayaran akan sesuai dengan PSAK 58 yang mengatur aset tidak lancar yang tersedia untuk dijual.

Aset tidak lancar menurut PSAK 1 adalah aset tetap, aset tidak berwujud, dan aset keuangan yang bersifat jangka panjang,jadi PSAK 58 menyatakan aset tidak lancar yang dimiliki untuk di jual adalah aset tidak lancar yang di peroleh khusus dengan tujuan untuk di jual kembali. Kriteria suatu aset tidak lancar atau kelompok aset lepasan dapat diklasifikasikan sebagai aset dimiliki untuk dijual adalah sebagai berikut:

a. Aset harus tersedia dan berada dalam keadaan dapat dijual dan penjualannya harus sangat mungkin terjadi (bighly probable);

b. Aset ini sudah dipasarkan secara aktif pada harga yang cukup masuk akal sesuai dengan nilai wajarnya kini;

c. Penjualan harus sudah diselesaikan, atau diharapkan dapat diselesaikan dalam jangka waktu 12 bulan sejak tanggal klasifikasi; dan

d. Tindakan yang diperlukan untuk menyelesaikan rencana tersebut sudah dilakukan sehingga mengindikasikan tidak mungkin terjadi perubahan signifikan atau pembatalan atas rencana tersebut.

Bitcoin sebagai alat pembayaran akan sesuai dengan PSAK 58 yang mengatur aset tidak lancar yang tersedia untuk dijual dimana aset tidak lancar yang dimiliki untuk dijual pada nilai yang lebih rendah antara jumlah tercatat dengan dan nilai wajar setelah dikurangi biaya untuk menjual

\section{Persediaan}

Bila perusahaan yang memiliki bitcoin bertidak sebagai trader atau broker di mana bit coin dibeli dan dijual dalam waktu dekat dan memperoleh laba atau margin, maka bitcoin diperlakukan sebagai persediaan.

PSAK Cryptocurrency Persediaan

Persediaan menurut PSAK 16 adalah yang tersedia untuk di jual dalam kegiatan usaha, dalam proses produksi untuk penjualan tersebut dan dalam bentuk bahan atau perlengkapan untuk digunakan dalam proses produksi atau pemberi jasa. Bitcoin memenuhi kiiteria sebagai persediaan, di mana pengukuranya menggunakan PSAK 14 tentang 
persediaan dimana entitas untuk mengukur komoditasnya dengan nilai wajar dikurangi biaya untuk menjual dengan selisih nilai wajar diakui dalam laba rugi. Hal ini di asumsikan Bitcoin sebagai komoditas pedagang komoditi seperti halnya pialang saham.

\section{Mata uang dasar (Base Curency).}

Negara yang menerima bitcoin sebagai alat pembayaran antara lain:

a. Amerika Serikat

Pemerintah Amerika telah melegalkan bit coin sebagai mata uang legal. Hal ini wajar karena bitcoin berasal dari Amerika dan telah ribuan outlet di Amerika menggunakan bitcoin sebagai pembayarn. Bahkan ada peraturan baru yang dikeluarkan oleh pemerintah Amerika untuk memeriksa mata uang digital yang dimilikinya.Aturan ini digagas oleh Sean Chuck Grassley pada tanggal 25 mei 2017.

b. Jepang

Di tahun 2017 jepang menerima bitcoin sebagai mata uang legal hal ini di tandai dengan 4.500 outlet menerima pembayaran dengan mata uang digital

c. Demark

Denmark adalah negara yang sangat maju dalam bidang teknologi dan menjadi negara yang paling sering berkampanye serta persuasi tentang penghapusan mata uang tunai dan menggantukanya dengan mata uang digital. Hal ini yang membuat Denmark melegalkan penggunaan bitcoin.

d. Rusia

Pada November 2016 pemerintah Rusia melalui Lembaga Pajak Federal Rusia secara resmi melegalkan penggunaan bitcoin. Hal ini didasari kesadaran bahwa teknologi digital di masa depan akan semakin besar dan sering digunakan dalam bertransaksi di masa depan, serta dapat mengawasi jalanya transaksi cryptocurrency sehingga mengurangi resiko terhadap penggunaan mata uang digital seperti money laundry dan pendanaan terorisme

e. Korea Selatan

Pada tanggal 3 Juli 2017 Park Yong Jin mengumumkan revisi perihal naskah peraturan untuk bata uang digital yang akan di syahkan berapa bulan ke depan yang isinya mata uang bitcoin dan ethereum akan menjadi legal. Korea selatan orang sudah biasa melakukan pembelian atau top up bitcoin di gerai 7-Eleven, bahkan Korea Selatan menjadi tuan rumah konferensi bitcoin reguler dan menjadi kominitas yang myaman dan terbuka bagi pegguna bitcoin.

f. Filandia

Filandia salah satu negara terdepan dalam hal perkembangan teknologi digital, dan adanya kebebasan pajak untuk pembelian bitcoin. ATM di Finlandia hampir seluruhnya di fasilitasi untuk melakukan penukaran dan top up bitcoin. Finlandia adalah negara yang transaksinya penukaran bitcoinya paling tinggi di bandingkan dengan negara lain.

Gambaran tersebut menunjukkan bahwa transaksi bitcoin mulai diterima di seluruh dunia. Walaupun hanya sebagian kecil negara yang menerima, namun masih banyak negara lain yang belum menerima dan menganggap bitcoin dapat digunakan sebagai transaksi. Hal ini menjadi perhatian serius untuk dikaji sehingga bitcoin memiliki kejelasan aturan yang mendasari. Bitcoin harus disusun dalam peraturan sehingga dapat dilegalkanya itu peraturan mengenai bagaimana memperlakukan transaksi cryptocurrency 
Dari praktek akuntansi untuk cryptocurrencyyang dikemukakan di atas, dapat disimpulkanbelum ada perlakuan yang pasti baik dari IFRS dan PSAK.Hal senada dinyatakan olehErsa Tri Wahyuni (2018) bahwaperlakuan terhadap cryptocurrencydalam pelaporan keuangan di indonesia masih belum pastidisebabkan antara lain:

1. Apakah bitcoin di anggap sebagai mata uang tradisional sehingga di anggap kas atau setara kas ( PSAK 50 pp 03 ) dimana mata uang (kas) adalah aset keuangan karena merupakan alat tukar.

2. Apakah perusahaan yang menggunakan bitcoin, memiliki bitcoin ini untuk tujuan investasi sehingga investasi bitcoin dianggap sebagai aset keuangan dan tunduk pada standar PSAK atau IFRS sebagai instrument keuangan tapi Instrumen keuangan (financial instrument)adalah kontrak yang mengakibatkan timbulnya aset keuangan bagi satu entitas dan kewajiban keuangan atau instrumen ekuitas bagi entitas lainnya. Bila perusahaan memiliki Bitcoin, maka perusahaan tidak memiliki hak kontraktual untuk menerima kas atau aset keuangan lainnya

3. ApakahCryptocurrency sebagai aset tak berwujud(PSAK 19) Namun PSAK 19 lebih mengatur aset tak berwujud kategori tidak lancar yang dimanfaatkan atau digunakan oleh perusahaan seperti misalnya hak paten, merk, royalti, piranti lunak, dan sebagainya, atau sebagai aset tersedia untuk di jual (PSAK 58) bila menerima bitcoin sebagai pembayaran. Sedangkan apabila entitasnya menggunakan jual beli bitcoin bertindak sebagai broker atau trader, PSAK 14meminta entitas untuk mengukur komoditasnya dengan nilai wajar dikurangi biaya untuk menjual dengan selisih nilai wajar diakui dalam laba rugi.

\section{KESIMPULAN}

Cryptocurrency adalah mata uang virtual yang bisa untuk bertransaksi keuangan onlime, yang tidak diatur oleh negara manapun. Cryptocurrency ini memilikibeberapa kelebihan antara lain mudah digunakan, dapat dikirim kemana saja,kapan saja, dimana saja, melalui internet, keamanan data pribadi, dan transaksi serta biaya yang relatif rendah. Cryptocurrencysebagai sistem transaksi keuangan dan sebagai mata uang digital merupakan teknologi yang relatif baru dan perlu penelitian serta pengkajian lebih lanjut terutama untuk akuntansi bagi transaksi Cryptocurrency untuk antara lain:

1. Cryptocurencies sebagai kas atau instrumen keuangan

Standar akuntansi bila bitcoin dinyatakan kas atau setara kas sesuai PSAK 50 pp 03 kas adalah aset keuangan yang merupakan alat tukar. Walaupun bitcoin digunakan untuk pembayaran tetapi bitcoin belum di anggap sebagai alat tukar yang legal di beberapa negara termasuk indonesia. Bitcoin digunakan sebagai investasibila dimasukan sebagai instrumen keuangan, namun bitcoin tidak memenuhi hal kontraktual untuk menerima aset keuangan lainya karena bitcoin dianggap sebagai emas batangan yang tidak bisa dianggap sebagai instrumen keuangan walaupun sifatnya likuid.

2. Cryptocurrency sebagai aset tidak berwujud atau persediaan

Standar akuntansi PSAK 19 bila bitcoin tidak bisa dianggap aset tidak berwujud seperti goodwill, royalti, hak paten, piranti lunak dan lain lain. Bitcoin bila diterima sebagai alat pembayaran maka akan sesuai degan PSAK 58 sebagai aset tersedia untuk di jual.Bila entitas yang menggunakan bitcoin bertindak sebagai trader atau broker maka bitcoin dianggap sebagai persediaan sesuai PSAK 14, dalam hal ini bitcoin dianggap sebagai emas batangan,

3. Cryptocurrency sebagai mata uang asing dan mata uang dasar 
Standar PSAK 10 bitcoin dianggap sebagai mata uang asing, namun bitcoin tidak memenuhi persyaratan sebagai mata uang fungsional. Bitcoinsebagai mata uang dasar belum memenuhi persyaratan karena tidak semua negara melegalkan bitcoin sebagai alat pembayaran, baru enam negara yang melegalkan bitcoin sebagai alat pembayaran sehingga bitcoin belum bisa dikatakan sebagai mata uang dasar.Dapat dikatakan Cryptocurrency bukan mata uang yang sah dan resmi karena tidak adanya otoritas yang berwenang untuk menerbitkan dan mengatur sehingga masih diragukan pertanggungjawabanya

4. IFRS dan PSAK dirasakan kurang memberikan panduan tentang aset tidak berwujud yang dimiliki untuk investasi seperti emisi karbon yang dibeberapa negara diperjualbelikan secara aktif dan juga PSAK dan IFRS kurang mengatur pada komoditas seperti emas batangan.Belum adanya kerangka PSAK dan IFRS yang memberi panduan lebih jelas tentang perlakuan akuntansi untuk bitcoin dan Cryptocurrency. Hal ini menjadi pertimbangan untuk IASB dan FASB serta IAI untuk tidak mengeluarkan akuntansi untuk Cryptocurrency.

\section{REFFERENSI}

Bunjanku, Flamur.et al 2017. CRYPTOCURRENCIES - ADVANTAGES AND DISADVANTAGESeprints.ugd.edu.mk/18707/1/Cryptocurrencies.pdf

Conway, J. (2014). Beginners Guide to Cryptocurrencies, 1-10.

Berentsen,Aleksander and SchärFabian. 2018.A Short Introduction to the World of Cryptocurrencies. Federal Reserve Bank of St. Louis Review, First Quarter 2018, 100(1), pp. 1-16.https://doi.org/10.20955/r.2018.1-16

Danella, Tiara Dhana; Sihabuddin, Hamidah. (2015). Bitcoin Sebagai Alat Pembayaran Yang Legal DalamTransaksi

Online.http://hukum.studentjournal.ub.ac.id/index.php/hukum/article/view/89 8/889

Dourado, Eli dan Jerry Brito. (2014). Cryptocurrency.The New Palgrave

Ersa Tri Wahyuni, 2012, Menggagas Akuntansi Untuk Cryptocurrencies. majalah Akuntan Indonesia edisi Februari 2018

Gormez, Y. \& Capie, F. 2003. Prospects for Electronic Money: A US - European Comparative Survey. Working Papers 0302. Research and Monetary Policy Department, Central Bank of the Republic of Turkey.

Ivashchenko A. I. 2016, Using Cryptocurrency in the Activities of Ukrainian Small and Medium Enterprises in order to Improve their Investment Attractiveness. Проблеми економіки № 3,2016

Midab. 20 Agustus 2017. Apa Itu Cryptocurrency- Seri Belajar Cryptolocho \#1.Cryptolocho.com https://goo.gl/8y]SPt

Mulyanto.Ferry. 2015 IJNS - Indonesian Journal on Networking and Security - Volume 4 No 4 - 2015 ijns.org

Nakamoto, S. (2008). Bitcoin: A Peer-to- Peer Electronic Cash System. Consulted, 19.http://doi.org/10.1007/s10838-008-9062-0

Syamsyah, Nurfia Oktaviani. 2017, Indonesian Journal on Networking and Security - Volume 6 No 1 2017

Waspada, Ikaputera. (2012). Percepatan Adopsi Sistem Transaksi Teknologi Informasi Untuk Meningkatkan Aksesibilitas Layanan Jasa Perbankan. Jurnal Keuangan dan Perbankan Vol 16 No. 1 Tahun 2012.

Zigman, Marty. Three Methods for Simple Bitcoin Business Accounting. https://bitcoinmagazine.com/articles/three-methods-simple-bitcoin-business-accounting1427833704/ 